\section{La cuestión de la «paz democrática» en la historia de las guerras contemporáneas}

Cristian Buchrucker

Susana Dawbarn de Acosta

Cristian Buchrucker es Investigador del CONICET en la Universidad Nacional de Cuyo.

Susana Dawbarn de Acosta es Investigadora del CONICET y Profesora en la Universidad Nacional de Cuyo.

Dirección Postal: Facultad de Filosofía y Letras / Centro Universitario, Parque General San Martín, 5500 Mendoza.

e-mail: buchruckerc@logos.uncu.edu.ar

\section{Resumen}

La tesis de la "paz democrática» se ha convertido en uno de los focos más interesantes del debate actual sobre la historia de las guerras. Este artículo analiza críticamente los trabajos más destacados acerca del tema, entre ellos los de Weart (1998), Geller y Singer (1998), Midlarsky (2000), Mansfield y Snyder (2007) y Gat (2008), confrontándolos con investigaciones de un equipo encabezado por los autores. Si bien algunos estudiosos han sostenido que existen por lo menos ocho casos históricos (entre 1812 y 1999) que pondrían en duda la validez de la mencionada tesis, una revisión cuidadosa de los mismos permite afirmar que sigue bastante sólida, salvo en lo que se refiere a intervenciones encubiertas que no llegan al nivel de intensidad de la guerra clásica.
Este trabajo expone los resultados parciales de un proyecto de investigación iniciado en 2007. Una primera versión fue presentada en las VI Jornadas Nacionales y I Foro Internacional de Historia Moderna y Contemporánea, Universidad Nacional de Lanús, septiembre de 2008.

\section{Summary}

The "democratic peace» thesis is one of the most interesting foci of the present debate about the history of wars. This article presents a critical analysis the most important contributions to this subject, such as those of Weart (1998), Geller and Singer (1998), Midlarsky (2000), Mansfield and Snyder (2007) and Gat (2007), confronting them with the research of a team headed by the authors. Although some scholars have maintained that there are at least eight historic cases (wars between 1812 and 1999) which could raise doubts about the validity of the above mentioned thesis, a careful check of those cases comes to the conclusion that it still is a quite solid one, except when we deal with covert interventions below the level of wars in the classic sense of the word. 